\title{
HUBUNGAN KECERDASAN SOSIAL DENGAN KEMEMPUAN KERJ SAMA DALAM KELOMPOK BELAJAR MAHASISWA PGSD SEMESTER I UNIVERSITAS PALANGKARAYA
}

\author{
Oleh: Ichyatul Afrom
}

\begin{abstract}
ABSTRAK
Dalam penelitian ini terdapat tujuan yang ingin dicapai, oleh peneliti guna memperdalam ilmu pengetahuan dan wawasan yang berkaitan dengan hubungan kecerdasan sosial dengan kerja belajar kelompok peserta didik. Adapun tujuan dalam penelitian ini adalah sebagai berikut: Untuk mengetahui hubungan antara kecerdasan sosial dengan kemampuan kerja sama dalam kelompok belajar mahasiswa PGSD Semester 1 Universitas Palangka Raya

Metode penelitian digunakan sebagai acuan peneliti untuk melakukan penelitian, penggunaan metode yang tepat sangat berpengaruh terhadap hasil penelitian, dengan demikian maka penelitian ini menggunakan metode korelsional Maka dapat disimpulkan bahwa terdapat hubungan antara tingkat kemampuan peserta didik dalam belajar kelompok terhadap tingkat kecerdasan sosial peserta didik, semakin tinggi tingkat keserdasan maka akan berpengaruh positif terhadap kerja sama ketika terlibat dalam kegiatan belajar kelompok. Hal tersebut sesuai dengan hasil analisis yang diperoleh dari pengujian hipotesis dalam penelitian yang peneliti telah lakukan.
\end{abstract}

PENDAHULUAN

Interaksi sosial akan berlangsung dengan baik apabila pihak yang berinteraksi memperhatikan norma-norma yang berlaku dalam masyarakat, sebaliknya interaksi akan terhambat apabila pelaku tidak memperhatikan norma atau aturan yang berlaku dalam masyarakat. Melalui proses pembelajaran yang diselenggarakan dalam dunia pendidikan secara formal, pendidik menjadi tolak ukur dari keberhasilan pembelajaran. Hal tersebut sesuai dengan tujuan pendidikan nasional yaitu untuk berkembangnya potensi mahasiswa agar menjadi manusia yang beriman dan bertakwa kepada Tuhan Yang Maha Esa, berakhlak mulia, sehat, kreatif, mandiri, dan menjadi warga Negara yang demokratis serta bertanggung jawab. Sedangkan upaya yang dapat dilakukan oleh pendidik dalam mengembangkan kemampuan kecerdasan sosial pada mahasiswa dapat melalui penggunaan metode kerja kelompok karena memungkinkan untuk mahasiswa untuk bekerja sama dengan teman sekelompoknya. 
Menurut Mohammad Asrori (2007:116), terdapat empat tahap proses pengembangan hubungan sosial yang harus dilalui oleh anak, yaitu; (a). anak ditutut agar tidak merugikan orang lain, menghargai, dan menghormati orang lain; (b). anak dituntut untuk mentaati peraturanperaturan dan berinteraksi dengan teman kelompok; (c). anak dituntut untuk lebih dewasa didalam melakukan interaksi sosial berdasarkan azas saling memberi dan menerima; (d). anak dituntut untuk saling memberi dan menerima dengan orang lain.

Berdasarkan hasil pengamatan di Universitas Palangka Raya Program Studi PGSD Semester 1, peneliti memperoleh gambaran bahwa, setiap mahasiswa terlihat saling berinteraksi (berhubungan) dengan mahasiswa yang lain baik di dalam ruangan maupun di luar ruang, interaksi ini juga terjadi pada saat proses pembelajaran yakni antara mahasiswa dengan mahasiswa, mahasiswa dengan pendidik.

Berdasarkan paparan di
atas maka peneliti dapat merumuskan masalah yang muncul adalah sebagai berikut: Bagaimana hubungan antara kecerdasan sosial dengan kemampuan kerja sama dalam kelompok balajar mahasiswa semester 1 Program Studi PGSD Universitas Palangka Raya?

Tujuan yang ingin dicapai, oleh peneliti guna memperdalam ilmu pengetahuan dan wawasan yang berkaitan dengan hubungan kecerdasan sosial dengan kerja belajar kelompok mahasiswa. Adapun tujuan dalam penelitian ini adalah sebagai berikut: Untuk mengetahui hubungan antara kecerdasan sosial dengan kemampuan kerja sama dalam kelompok belajar mahasiswa semester 1 Program Studi PGSD Universitas Palangka Raya.

\section{Pengertian Kelompok}

Pengertian kelompok

menurut Bales (Abu Huraerah \& Purwanto, 2005:3), mengatakan bahwa:

Kelompok adalah sejumlah individu yang berinteraksi dengan sesamanya secara tatap muka atau serangkaian pertemuan, dimana masing-masing anggota tersebut saling menerima impresi atau persepsi anggota lain dalam suatu waktu tertentu dan 
menimbulkan

pertanyaan-pertanyaan

kemudian, yang membuat masingmasing anggota bereaksi sebagai reaksi individu.

\section{Keceradasan Sosial}

a. Pengertian kecerdasan

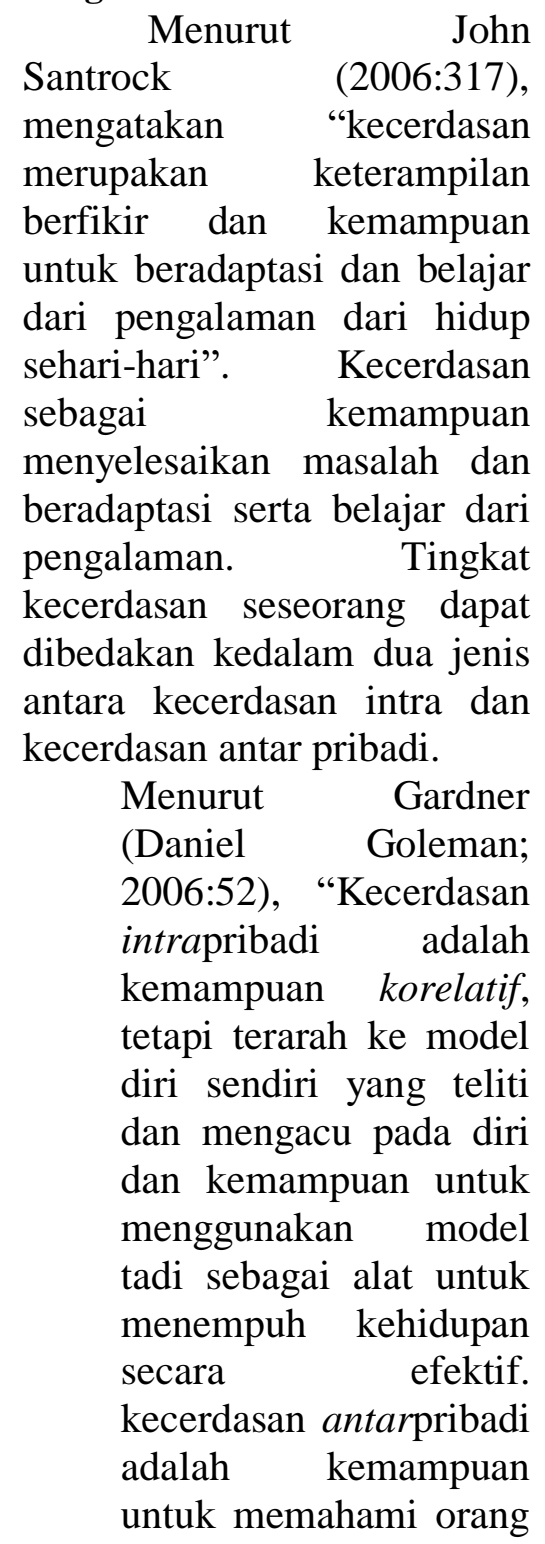

$\begin{array}{lr}\text { lain: apa } & \begin{array}{r}\text { yang } \\ \text { memotivasi }\end{array} \\ \text { mereka, } \\ \text { bagaimana } & \text { mereka, } \\ \text { bagaimana } & \text { mereka } \\ \text { bekerja, bagaimana } & \text { baima } \\ \text { bekerja bahu-membahu } \\ \text { dengan mereka". }\end{array}$

Berdasarkan pendapat di atas dengan demikian kecerdasan tidak dapat diukur secara langsung. Seseorang hanya dapat mengamati dan mengevaluasi kecerdasan secara tidak langsung dengan cara mempelajari dan membandingkan tindakan kecerdasan yang ditunjukan oleh orang-orang. Kecerdasan antar pribadi melibatkan sebuah usaha untuk membangun kerjasama dengan orang lain yang sering dilakukan dalam lingkup sosial.

\section{b. Pengertian sosial}

Sosial adalah berkenaan dengan masyarakat (kamus Besar Bahasa Indonesia 2002:855), perlu adanya komunikasi dalam usaha menunjang pembangunan dalam sekelompok masyarakat serta untuk menunjang kepentingan umum. Interaksi yang terjadi di dalam lingkungan masyarakat maupun sekolah tidak lepas dari masalahmasalah sosial yang muncul. Sedangkan Menurut Nisbet (SulaemanMunandar, 
2000:06), pengertian masalah sosial memiliki dua pendefinisian:

Pertama, pendefinisian menurut umum, kedua, menurut para ahli. Menurut umum atau warga masyarakat, segala sesuatu yang menyangkut

kepentingan umum adalah masalah sosial. Menurut para ahli, masalah sosial adalah suatu kondisi atau perkembangan yang terwujud dalam masyarakat yang berdasarkan atas studi, mempunyai sifat yang dapat menimbulkan kekacauan terhadap warga masyarakat secara keseluruhan.

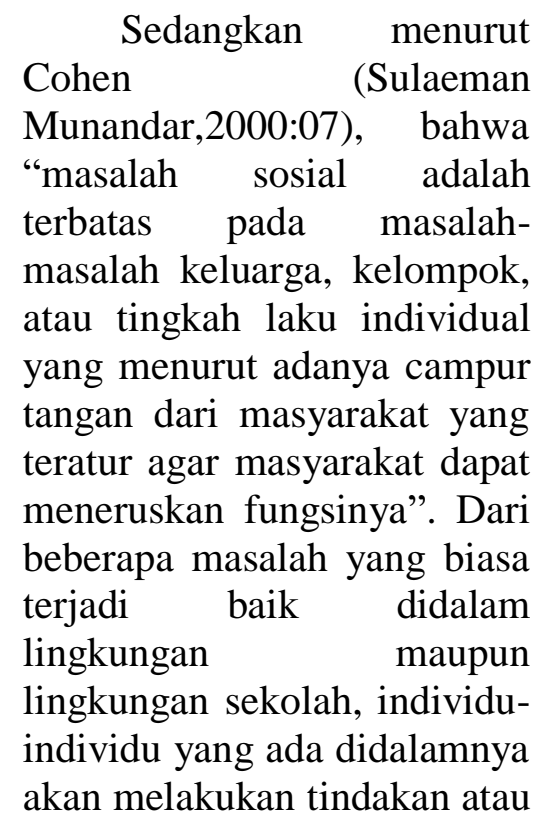

sikap untuk mengambil keputusan atau kebijakan yang memungkinkan untuk menyelesaikan masalah yang terjadi.

Sikap sosial secara umum adalah hubungan antar manusia dengan manusia yang lain, saling kebergantungan dengan manusia lain dalam berbagai berkehidupan bermasyarakat (Zulkifli, L;1992:45). Sikap sosial ini akan terjadi karena adanya sistem yang memungkinkan seseorang untuk melakukan hubungan sosial, menurut Talcot Parsons (Sulaeman Munandar, 2000:27), konsep sistem sosial adalah;

Alat pembantu untuk
menjelaskan tentang
kelompok-kelompok
manusia. Model ini
bertolak dari pandangan
bahwar kelompok-
kelompok manusia
merupakan ruatu
system. rap-tiap
system sosial terdiri
atas pola-pola perilaku
tertentu rang
mempunyai struktur
dalam dua arti, yaitu:
pertama, relasi-relasi
sendiri antara orang-
orang bersifat agak
mantap dan tidak
mudah berubah; kedua,

Alat pembantu untuk menjelaskan tentang kelompok-kelompok manusia. Model ini bertolak dari pandangan bahwa kelompokkelompok manusia merupakan suatu system. Tiap-tiap system sosial terdiri atas pola-pola perilaku tertentu yang mempunyai struktur dalam dua arti, yaitu: pertama, relasi-relasi sendiri antara orangorang bersifat agak mudah berubah; kedua, 
perilaku-perilaku mempunyai corak atau bentuk yang relatif mantap.

\section{PEMBAHASAN}

Berdasarkan penelitian yang dilakukan pada mahasiswa PGSD Universitas Palangkaraya semester I dengan mengangkat judul "Hubungan kecerdasan sosial dengan kemampuan kerja sama dalam kelompok belajar mahasiswa PGSD semester I Universitas Palangka Raya" dengan menggunakan observasi dan koesioner/koesioner yang digumakan sebagai alat bantu untuk mengumpulakan bahan/data yang diperlukan guna menunjang penelitian.

Berdasarkan angket yang disebar dalam penelitian menunjukan rata-rata setiap mahasiswa memiliki kecerdasan sosial sedang. Kecerdasan sosial mahasiswa yang tinggi maka akan mempengaruhi kemampuan mahasiswa dalam belajar kelompok. Hal tersebut dapat dibuktikan dengan adanya hubungan yang kuat anatara kecerdasan sosial terhadap kemampuan belajar kelompok mahasiswa sebesar 0,882 lebih besar dibandingkan dengan $r$ tabel 0,423 .

\begin{tabular}{llr}
\multicolumn{3}{r}{ Kecerdasan sosial ini akan } \\
sanagat berpengaruh & ketika \\
mahasiswa bekerja sama dalam
\end{tabular}

kelompok belajar hal tersebut dapat terlihat pada saat individu berperan dan melaksanakan tugasnya sebagai bagian dari kelompok belajar, semakin tinggi sikap sosial yang dimiliki mahasiswa maka akan mudah bekerja sama dalam kelompok belajarnya. Dengan demikian kecerdasan sosial yang dimiliki oleh setiap mahasiswa memiliki peran penting terhadap kemampuan belajar kelompok mahasiswa.

\section{DAFTAR PUSTAKA}

Huraeroh Abu, \& Purwanto , 2005. Dinamika Kelompok, Bandung: Refika Aditama.

Kamus Besar bahasa indonesi, 2005, Jakarta: kompas

Kartadinata Sunaryo, 1999. Bimbingan di Sekolah Dasar, DEPDIKBUD

Margono, 2007. Metodologi Penelitian Pendidikan.Jakarta:Rineka Cipta.

Muijs, Daniel \& Reynolds, David, 2008. Efektive Teaching, Yogyakarta: Pustaka Pelajar.

Munandar, Sulaeman, 2000. Ilmu Budaya Dasar, Bandung: Revika Aditama

Nazir, Moh, 2005. Metode Penelitian, Bogor: Ghalia Indonesia.

Roestiyah, N.K.,2008. Strategi Belajar Mengajar, Jakarta: Renika Cipt 